„Standard“, этот вариант в значительной степени вытеснен принятым в качестве нормы в Германии вариантом с ,auf":

VfGH hebt über Antrag des OGH Bestimmungen des Fortpflanzungsmedizingesetzes auf [Официальный сайт Верховного суда Австрии].

„Wahlkarten gibt's auf Antrag“; ÖVP kritisiert FPÖ [www.meinbezirk.at].

Анализ подобных моделированных сочетаний в устной речи носителей австрийского варианта немецкого языка представляется нецелесообразным, поскольку они относятся к официально-деловому стилю и поэтому более характерны для письменной речи. Однако в перспективе мы планируем рассмотреть изменения, которые затронули другие устойчивые по форме предложно-именные сочетания, в частности, конструкции с предлогом „zи“ и абстрактным именем существительным (часто названием праздника) в значении «к определённому моменту времени» (zu Ostern, zu Neujahr, zum Jahreswechsel и др.).

Таким образом, можно сделать вывод о том, что в австрийском варианте немецкого языка непрерывно происходят изменения под влиянием немецкого языка Германии, в том числе на грамматическом уровне. Данные изменения наблюдаются, прежде всего, в речи молодого поколения, а также в языке прессы. Неравномерное вытеснение австрийских вариантов вариантами из немецкого языка Германии связано с различной степенью распространения диалекта, а также с культурной близостью к Германии отдельных регионов.

статья выполнена в рамках стажировки в Институте гуманитарных наук г. Вена, Австрия (InstitutfürdieWissenschaftenvomMenschen) при поддержке гранта Благотворительного фонда культурных инициатив (Фонда Михаила Прохорова)

$$
* * *
$$

1. Duden. Österreichisches Deutsch. Mannheim, Leipzig, Wien, Zürich: Dudenverlag, 2008, 52 S.

2. Peter, Klaus. Sprachliche Normvorstellungen in Österreich, Deutschland und der Schweiz. In: Dimensionen des Deutschen in Österreich: Variationen und Varietäten im sozialen Kontext / Alexandra N. Lenz, Timo Ahlers, Manfred M. Glauninger (Hrsg.). Frankfurt am Main: Peter Lang GmbH, 2015, S. 123 - 147.

3. Wiesinger, Peter. Das österreichische Deutsch in der globalisierten Umwelt: Wandlungen durch bundesdeutsche Einflüsse. In: Dimensionen des Deutschen in Österreich: Variationen und Varietäten im sozialen Kontext / Alexandra N. Lenz, Timo Ahlers, Manfred M. Glauninger (Hrsg.). Frankfurt am Main: Peter Lang GmbH, 2015, S. 91-122.

\title{
Semenova E.M. \\ «Uniformity - diversity» as the basic archetypical metaphorical opposition of American linguistic culture
}

SPbUTME

(Russia, Saint-Petersburg)

doi: $10.18411 /$ spc-26-03-2018-12

idsp: 000001:spc-26-03-2018-12

Over the last decades more and more countries throughout the world have been facing increasing ethnic, cultural and linguistic diversification within their borders. It's becoming crucially vital to come to terms with these changes, which are now occurring not only in policy but our everyday life as well. A great deal of research in the Humanities is focusing nowadays on a range of topics related to multiculturalism from the perspectives of different disciplines among which linguistics occupies one of the prominent places.

Modern forms of the world perception, broadening and making endless the borders of cognition due to the developing of new technologies and mass-media means of transmitting information at the same time "deactualizes" the necessity to "switch on" the individual senses 
of the cognizing subject. Being widely informed, the modern person loses the ability to feel the experience of the community he belongs to.

As the feeling, according to Ortega-and Gasset is "the ability to percept the distinctions, which catches the diverse and changeable but getting blunt and blind in front of stable and constant" [3], it seems quite logical to suppose that metaphor, as the means of perception the world through the feelings can be regarded as the phenomenon giving a real chance to "catch" constantly changing Parts constituting the comprehensive Whole.

It should be mentioned that a great number of scientists regard metaphor not only as a linguistic phenomenon but as one of the world conceptualization means, and, in addition, as the way to create new meanings. Subsequently, the determination of metaphor status as a lingo-cultural category seems to have been still topical.

Special interest is being paid nowadays to so-called archetypical metaphor (M. Osborn's term) as it seems that the addressing to universal axiological reference points can help throw the light on the role of metaphor in the process of philosophical comprehension and conceptualization of the "being" by the individual who belongs to this or that culture $[4,5]$. That's why the phenomenon of national unity as well as diversity is supposed to be better viewed through such linguistic means as metaphor due to its ontological nature.

This idea definitely correlates with the basic archetypical opposition of American linguistic culture "UNIFORMITY - DIVERSITY», which being represented by various metaphors, is likely to be regarded as a promising way to find out some of the consistent patterns and peculiarities of the multicultural American society.

The research made demonstrated that while describing American Nation the speakers appeal to such metaphorical images as "melting pot", "vegetable soup", "salad bowl", "ethnic stew", "tomato", "dressing" and "fabricof one America" each of which reveals a certain vision of the multinational American society in different periods of its history. Thus, the necessity to keep cultural identity led to transforming the "dead" metaphorical image of "melting pot" (where all the nationalities "melt" into one substance) into "salad bowl" (where the mixture of a multitude of ingredients presupposes the ability to "save" their own "taste").

L. Lobeva's study dealing with multiculturalism and nationality minoritiesproblem in Prague University (Check Republic), we see the following speculation concerning American Nation origin:

«The shortages of the melting pot and salad bowl paradigms can be expressed in the following summarizing parables: In the case of the melting pot the aim is that all cultures become reflected in one common culture, however this is generally the culture of the dominant group - I thought this was mixed vegetable soup but I can only taste tomato. In the case of the salad bowl, cultural groups should exist separately and maintain their practices and institutions, however, "Where is the dressing to cover it all?" Hopefully the solution may be offered by the concept of the ethnic stew where all the ingredients are mixed in a sort of panHungarian goulash where the pieces of different kinds of meat still keep their solid structure» [2].

For a long period of time American nation formation was associated with a "melting pot" image, in which different "metals" (peoples having settled on the American continent searching for a better life), after having undergone high temperatures (trials they had to go through), melted (lost their unity) and organized a new conjunction (universal community called American nation).

Such kind of metaphorical understanding of American nation origin points out to the fact that settlers were ready to refuse from their Motherland for the sake of the opportunity to start a new life and realize their American Dream. This type of conceptualization correlated with the cultural assimilation theory and was actual until the year 1908 (when a new wave of Western Europe immigrants came to the USA), but with the change of the social-political situation connected with the restrictions introduced to the entry in the country and no wish to 
be assimilated with the other races and people on the part of the Europeans, this conceptualization seemed more and more argumentative.

The hesitations concerning this metaphorical model are actualized in the given abstract by means of the proposition «I thought this was mixed vegetable soup but I can only taste tomato», in which the collocation «mixed vegetable soup» represents an ideal model of the state where all the peoples (vegetables) have equal opportunities for self-expression being the UNITY (soup), and the phrase «but I can only taste tomato» explicits the disappointment caused by the real state of things in the country where only one, European race(tomato) dominates.

The urgency of keeping cultural identity and the wish to escape the loosing of the "roots" initiated the occurrence of another metaphorical image - «the salad bowl», which helps to visualize the American Nation concept in terms of a dish where the mixture of plentitude of ingredients (cultural interaction of various peoples) presupposes saving of the individual taste of each distinct component (the keeping of cultural peculiarities, traditions and customs of all migrated peoples).

Such type of metaphorical conceptualization highlights (G'. Lakoff's term) the idea of cultural distinctiveness) [1], "shadowing" the conceptual foundation of the integration phenomenon which is the peculiar feature of American Nation. Speaking metaphorically, it's unclear "what the salad is covered by" (Where is the dressing to cover it all?).

This brief analysis shows that the idea of cultural distinctiveness reflected upon the integration phenomenon and having been dramatically popular for a substantial period of time has lost its meaning due to the inevitable social changes we can observe through metaphor used in lingvo-cultural context.

To sum up, it can be mentioned that the article discovers the idea of metaphor as an epistemological and ontological category representing the person's ability to realize the «being» as the whole entity consisting of numerous distinct elements.

The author distinguishes the basic archetypical American lingvo-cultural model UNIFORMITY - DIVERSITY, which is regarded as a universal philosophical category revealing its own particularity while being applied to the American world image notion.

The ontological essence of archetypical metaphor proved to provide the comprehension variety of innermost principles of Genesis account and let us notice the universal nature of Human in diverse conditions of His cultural manifestation.

$$
* * *
$$

1. Lakoff G., Johnson M. Metaphors we live by. University of Chicago Press: 1980; 2003. - 256 p.

2. Laubeova, Laura. Melting Pot vs. Ethnic Stew. Encyclopedia of the Worlds Minorities [Электронный pecypc] URL: http://www.tolerance.cz/courses/ text (дата обращения: 20.12.2017).

3. Ortega-and-Gasset X. Two main metaphors // Esthetics. Philosophy of Cilture. M.: The Art. pp.-203-218.

4. Osborn M. Archetypal Metaphor in Rhetoric: The Light-Dark Family // Quarterly Journal of Speech. 1967. Vol. 53.

5. Osborn M., Eninger D. Metaphor in Public Speech // Political Linguistics 1 (35). - 2011. pp. $244-253$. 